\title{
KAJIAN PERBAIKAN STRUKTUR PERKERASAN KAKU MENGGUNAKAN METODE PRESSURE GROUTING DENGAN MATERIAL POLYURETHANE DAN EPOXY (Studi Kasus : Ruas Jalan Patriot - Perintis Kemerdekaan Kota Pekalongan)
}

\author{
Arif Junianto ${ }^{1)}$, Rifqi M. Ramadhan ${ }^{1, *)}$, Jantayu P. Utari ${ }^{1)}$, Kusdiyono ${ }^{1)}$, \\ Dadiyono A.P ${ }^{1}$, Junaidi ${ }^{1)}$ \\ ${ }^{1)}$ Jurusan Teknik Sipil Politeknik Negeri Semarang \\ Jl. Prof. Soedarto SH, Tembalang Semarang 50275 Telepon (024) 76480569 \\ ${ }^{*}$ Email: rifqimramadhan@gmail.com
}

\begin{abstract}
Today the implementation of road infrastructure development using concrete pavement is experiencing rapid development because it can serve heavy and heavy traffic loads. But there are some problems that often arise in the use of concrete for pavement, causing damage (cracks). Repair of concrete cracks using pressure grouting method is one solution that can be used to improve the strength of concrete. This study discusses the comparison of the effectiveness of using polyurethane and epoxy materials in an effort to improve the rigid pavement structure. The research method used was to carry out repairs to the concrete structure on the Independence Patriotic-Road Section of Pekalongan City using polyurethane and epoxy materials. In this study each of the 5 existing normal (nondamaged) concrete samples, concrete repaired with polyurethane material and repaired concrete using epoxy material using core drill method, which will then be tested for compressive strength in the laboratory, as well as hammer test testing. to find out the strength of the existing concrete damage. The results showed that the average compressive strength of normal existing concrete (not damaged) amounted to $59.20 \mathrm{~N} / \mathrm{mm} 2$, the average compressive strength of concrete that experienced cracks was $27.04 \mathrm{~N} / \mathrm{mm} 2$, the average compressive strength value of repair concrete using polyurethane material is $31.92 \mathrm{~N} / \mathrm{mm} 2$ (increasing by $15.17 \%$ ) and the average compressive strength of concrete repair using epoxy material is 45.22 $\mathrm{N} / \mathrm{mm} 2$ (increased by $56.53 \%$ ).
\end{abstract}

Kata kunci : concrete crack repair, pressure grouting, polyurethane, epoxy

\section{PENDAHULUAN}

Dewasa ini pelaksanaan pembangunan infrastuktur jalan mengalami perkembangan yang cukup pesat. Pembangunan jalan menggunakan perkerasan beton merupakan satu pilihan yang sering kali digunakan karena didasari oleh hirarki fungsional jalan yang dapat melayani beban lalu lintas yang berat dan padat. Selain itu karena biaya pemeliharaan jalan beton yang sedikit dibandingkan dengan jalan aspal yang memerlukan pemeliharaan rutin. Namun ada beberapa masalah yang sering timbul dalam penggunaan beton untuk perkerasan jalan, antara lain disebabkan karena cuaca dan suhu, 
salah perencanaan ataupun akibat dari beban yang berlebihan dari kapasitas yang direncanakan serta akibat beban sementara seperti gempa sehingga menyebabkan adanya keretakan (cracks) pada struktur perkerasan jalan. Selain karena faktor curah hujan yang tinggi, kerusakan jalan juga disebabkan karena adanya overtonase atau kelebihan muatan kendaraan.

Oleh karena beberapa sebab diatas, seringkali didapati beberapa kerusakan pada struktur jalan beton. Dalam sebuah penelitian yang dilakukan oleh Supardi (2013) yang membahas mengenai evaluasi kerusakan jalan pada perkerasan kaku didapatkan data bahwa jenis kerusakan jalan didominasi oleh kerusakan retak, diikuti punch out dan kerusakan jalan berlubang. Kerusakan yang terjadi akan mempengaruhi kualitas layanan struktur jalan, oleh sebab itu perlu dilakukan upaya untuk mengembalikan fungsi dari jalan tersebut melalui perbaikan- perbikan.

Menurut Yurmansyah dan Mukhlis (2009), perbaikan pada retak yang terjadi pada plat lantai yaitu dengan cara grouting / suntikan bahan perekat. Metode ini adalah sesuatu cara perbaikan retak beton yang retaknya antara $0,2 \mathrm{~mm}$ sampai dengan $5,00 \mathrm{~mm}$ agar menjadi satu kesatuan kembali (homogen), sehingga retak beton dapat diperbaiki dan komponen beton dapat berfungsi kembali sebagaimana mestinya. Pekerjaan ini meliputi penyuntikan bahan perekat (grout) ke dalam retakan yang ada sampai terisi penuh.
Menurut Primasasti (2010), penggunaan material polymer sebagai repair material beton relatif mudah dibuat dan diaplikasikan di lapangan. Aggarwal, dkk (2005). Melakukan penelitian mengenai penggunaan material emulsi epoxy dan akrilik dalam penggunaannya sebagai repair material. Hasilnya menunjukkan bahwa penggunaan emulsi epoxy memiliki sifat kekuatan superior dan ketahanan yang lebih baik terhadap penetrasi ion klorida dan karbon dioksida.

Berdasarkan uraian di atas, penelitian ini akan mengkaji mengenai upaya perbaikan kerusakan struktur perkerasan kaku dengan metode pressure grouting menggunakan material epoxy dan polyurethane pada repair material yang dibandingkan dengan beton eksisting normal (tidak retak) dan beton eksisting yang telah mengalami kerusakan (retak).

Menurut SNI 2847:2013, beton adalah campuran semen portland atau semen hidrolis lainnya, agregat halus, agregat kasar, dan air, dengan atau tanpa bahan tambahan (admixture). Dalam pelaksanaan pekerjaan beton sering kali dijumpai keretakan beton (cracks), cracks beton adalah pecah pada beton dalam garis-garis yang relatif panjang dan sempit, retak ini dapat ditimbulkan oleh berbagai sebab, diantaranya adalah karena evaporasi air dalam campuran beton terjadi dengan cepat akibat cuaca yang panas, kering atau berangin. (Isneini, 2009). Sedangkan menurut Rokhman (2012), keretakan (cracks) pada struktur beton dapat disebabkan oleh dua hal yaitu 
retak akibat beban luar yang mengakibatkan terjadinya lentur atau geser atau kombinasi keduanya pada elemen beton dan yang kedua retak sebagai akibat dari proses pengeringan beton yang tidak seragam atau yang sering disebut retak susut (shrinkage crack).

Dachlan (2010) melakukan penelitian mengenai perbaikan kerusakan beton dengan metode injection. Menghasilkan bahwa dalam pelaksanaan dibutuhkan waktu sekitar 6 jam sebelum lokasi tersebut dapat dilalui lalulintas kendaraan.sambungan yang sudah diperbaiki menggunakan metode ini menghasilkan nilai defleksi kurang dari $0,05 \mathrm{~mm}$ atau penurunan nilai defleksi sebanyak $55 \%$ dari nilai sebelumnya.

Aggarwal, dkk melakukan penelitian mengenai penggunaan material emulsi epoxy dan akrilik dalam penggunaannya sebagai repair material. Menghasilkan bahwa penggunaan material polymer dapat mengurangi porositas pada material mortar, selain itu sebagian besar hasil tes yang dilakukan selama penelitian ini menunjukkan bahwa emulsi epoxy memiliki efek yang lebih besar pada peningkatan sifat-sifat mortar daripada akrilik. Keuntungan lainnya termasuk kemudahan dalam pembersihan peralatan dan peralatan setelah digunakan, bahaya kesehatan minimum dan penghematan biaya karena tidak ada penggunaan pelarut organik. Dengan demikian, emulsi epoksi lebih ramah lingkungan daripada epoksi berbasis pelarut.
Primasasti (2010) melakukan penelitian mengenai tinjauan kuat tekan dan kuat lentur repair mortar (mortar biasa, mortar dengan bahan tambah polymer dan BASF EMACO Nanocrete) menghasilkan nilai kuat tekan yang terbesar terjadi pada komposisi repair mortar PO-2 \% pada umur awal dan $\mathrm{PO}-4 \%$ pada umur 28 hari, nilai kuat lentur yang terbesar terjadi pada komposisi repair mortar PO-0\% dan nilai kekakuan yang terbesar terjadi pada komposisi repair mortar PO-0 \% pada umur awal dan PO-2\% pada umur 28 hari

Yurmansyah dan Mukhlis (2009) melakukan penelitian mengenai perkuatan struktur plat lantai dengan metode grouting dengan material glass fiber. Menghasilkan penggunaan mix ratio bahan grout dan seal komposisi 2 (base):1 (hardener), dengan nilai kekuatan tekan umur 7 hari minimal $500 \mathrm{~kg} / \mathrm{cm}^{2}$.

a. Beton

Menurut SNI 2847:2013, beton adalah campuran semen Portland atau semen hidrolis lainnya, agregat halus, agregat kasar, dan air, dengan atau tanpa bahan tambahan (admixture). Pada umumnya, beton mengandung pasta semen (semen dan air) 25\%-40\%, agregat (agregat halus dan kasar) $60 \%-75 \%$ dan udara 1\%-3\%.

Menurut Kusdiyono (2012) ada 3 fase pembentukan beton dalam keadaan plastis menjadi padat. Campuran pada keadaan plastis siap segera dituang kedalam cetakan dan dipadatkan sebelum mengikat (setting) dan biasa disebut dengan beton segar. Setelah 10 jam dari waktu pengecoran beton 
mulai mengeras, fase ini disebut beton muda, proses pengerasan akan berlangsung terus menerus sampai mencapai kekuatan beton yang disyaratkan disebut beton keras.

\section{b. Retak beton}

Menurut Isneini (2009) Cracks beton adalah pecah pada beton dalam garisgaris yang relatif panjang dan sempit, retak ini dapat ditimbulkan oleh berbagai sebab, diantaranya adalah karena evaporasi air dalam campuran beton terjadi dengan cepat akibat cuaca yang panas, kering atau berangin. Retak akibat keadaan ini disebut plastic cracking, Bleeding yang berlebihan pada beton, biasanya akibat proses curing yang tidak sempurna. Retakan bersifat dangkal dan saling berhubungan pada seluruh permukaan pada plat, retak jenis ini disebut crazing. Pergerakan struktur, sambungan yang tidak baik pada pertemuan kolom dengan balok atau plat, atau tanah yang tidak stabil. Retakan bersifat dalam atau lebar, retak jenis ini disebut random cracks. Reaksi antara alkali dan agregat, retakan yang terbentuk sekitar 10 tahun atau lebih setelah pengecoran dan selanjutnya menjadi lebih dalam dan lebar, retakan saling berhubungan satu sama lain.

Menurut Yurmansyah dan Mukhlis (2009) retakan pada beton dapat dibedakan menjadi 2 jenis, yaitu retak tidak aktif, retak ini tidak berkembang / stabil atau yang lebih dikenal dengan dead-craks. Dan yang kedua adalah retak aktif, retak ini masih berlanjut baik lebar maupun panjang retakan atau yang lebih dikenal dengan live cracks. Untuk kemudahan dalam menilai jenis retakan yang terjadi, lekatkan kaca tipis pada jalur retakan, yang sekaligus monitoring perkembangan retakan.

\section{c. Grouting}

Menurut Surat Edaran Menteri PUPR No. 27 tentang Pedoman Penstabilan Dan Pengembalian Elevasi Pelat Beton Dengan Cara Grouting Pada Perkerasan Kaku (2015), Grouting merupakan proses injeksi material grout kedalam atau kebawah pelat beton yang berfungsi untuk penstabilan pelat dan pengembalian elevasi plat yang turun. Pelaksanaan pekerjaan grouting dilakukan menggunakan material grout yang bersifat semen dan air, dengan atau tapa menggunakan penambahan agregat.

e. Repair material

Menurut Alfredo dkk. (2014), ada beberapa jenis material yang sering digunakan untuk melakukan perbaikan pada struktur beton di Indonesia, setiap material memiliki kelebihan dan kekurangan serta berbeda dalam fungsi penggunaannya diantaranya adalah semen grouting, epoxy resins, dan polyurethane.

1) Grouting cement

Material semen grouting, biasanya dipakai untuk memperbaiki kerusakan dengan skala cukup besar seperti kerusakan voids dikarenakan memiliki nilai yang lebih ekonomis dibandingkan polyurethane dan epoxy, namun setting time yang diperlukan sampe material ini untuk mengeras lebih lama dibandingkan polyurethane dan epoxy. Material ini mengandung 
campuran dari semen, filler, dan aditif yang tercampur secara homogen. Pengisi yang dipakai pada semen ini biasanya adalah pasir silika. Kandungan pasir silika menyebabkan semen memiliki keunggulan, yaitu tidak dapat menyusut.

2) Epoxy (resin bening)

Epoxy merupakan komponen yang mempunyai daya rekat yang sangat tinggi antara beton normal dengan repair material serta memiliki sifat permeabilitas yang rendah, material ini dapat mengisi celah keretakan hingga $0,1 \mathrm{~mm}$, selain itu material ini memiliki kekuatan yang sangat besar dan waktu setting yang cepat sehingga dapat digunakan pada lokasi yang aktif digunakan. Kekurangan dari material ini adalah harganya yang relative lebih mahal dibandingkan dengan cement grout dan polyurethane.

3) Polyurethane

Polyurethane (PU) merupakan salah satu bahan yang umum digunakan sebagai material perbaikan beton. Material ini memiliki keunggulan tahan gesek, tahan aus dan tahan terhadap beberapa bahan kimia serta stabil dalam suhu dingin dan panas. Bahan polyurethane dapat digunakan untuk mengatasi kebocoran aktif pada beton. Setelah diinjeksikan ke bawah pelat, reaksi kimia polyurethane akan mengakibatkan bahan mengembang dan mengisi rongga. Kuat tekan minimum adalah 1,0 MPa.

\section{METODE PENELITIAN}

Yurmansyah dan Mukhlis (2009) melakukan identifikasi kerusakan beton secara visual serta melakukan pengujian terhadap beton eksisting yang akan diperbaiki. Setelah dilakukan proses grouting, dilakukan pengambilan sample benda uji di lapangan untuk diuji dilaboratorium.

a. Survey dan persiapan

Tahapan ini mencakup permohonan ijin untuk melaksanakan penelitian dilapangan kepada Dinas Pekerjaan Umum dan Penataan Ruang Kota Pekalongan, dilanjutkan dengan survey lapangan untuk mendapatkan data visual lokasi yang akan diperbaiki, dan persiapan alat bahan yang akan digunakan pada saat peneltian. Menurut Surat Edaran Menteri PUPR No. 27 tentang Pedoman Penstabilan Dan Pengembalian Elevasi Pelat Beton Dengan Cara Grouting Pada Perkerasan Kaku (2015), alat dan bahan yang digunakan dalam pekerjaan grouting adalah sebagai berikut:

1) Alat yang digunakan

a) Grouting injection machine

Dalam penelitian ini digunakan mesin grouting produksi Guangzhou BDFL Waterproof Building Material dengan seri QY-99, adapun alat tersebut terdiri dari beberapa komponen diantaranya unit pembuat grout (grout plant) yang berfungsi untuk membuat campuran graut. Kemudian terdapat grout packer yang terdiri dari drive packer dan expandable packers, berfungsi untuk menginjeksikan bahan grout pompa injeksi, selanjutnya terdapat pompa injeksi yang berfungsi untuk memompa bahan graut dan memasukkannya ke dalam lubang 
injeksi dengan kecepatan dan tekanan tertentu, dan yang terakhir terdapat grout mixer dan agitator yang berfungsi untuk mencampur bahan grout sesuai dengan perbandingan yang ditentukan, kemudian dialirkan kedalam agitator sebagai tempat grout siap untuk diambil oleh pompa.

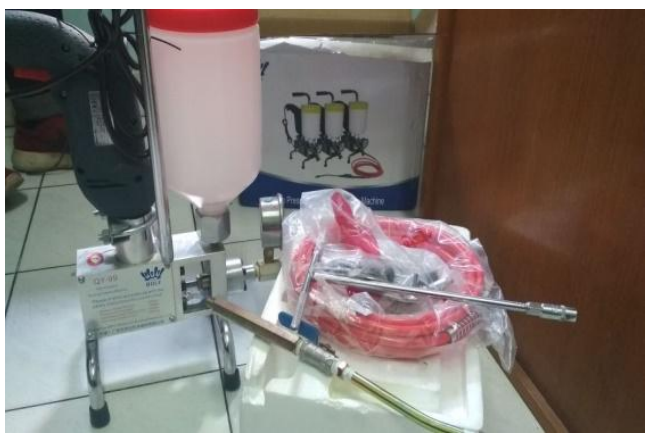

Gambar 1. Grouting Injection Machine

\section{b) Mesin bor}

Mesin bor dipakai untuk pembuatan lubang grout yang dapat menghasilkan lubang yang bersih tanpa menimbulkan gompal pada permukaan pelat atau kehancuran pada dasar pelat. Bor elektrikpneumatik dapat membuat lubang injeksi sampai dengan diameter lubang $15 \mathrm{~mm}$.

Pada penelitian ini digunakan bor merk RYU seri RID 13-1 RE dengan ukuran chuck $13 \mathrm{~mm}$ dan kecepatan putar hingga 2800 rpm yang dapat mengebor beton hingga diameter $16 \mathrm{~mm}$.

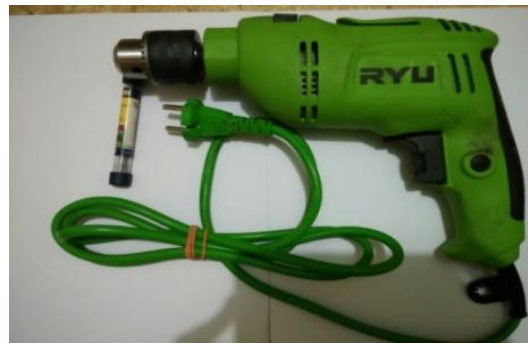

Gambar 2. Mesin Bor c) Mesin gerinda

Mesin gerinda, sikat kawat dan scrape adalah alat yang digunakan untuk membersihkan kotoran-kotoran dan bekas beton yang tidak sempurna dan bekas bahan penutup yang dibersikan kembali.

Pada penelitian ini digunakan gerinda merk Bosch dengan seri GWS 060 yang dapat berputar dengan kecepatan mencapai $12000 \mathrm{rpm}$.

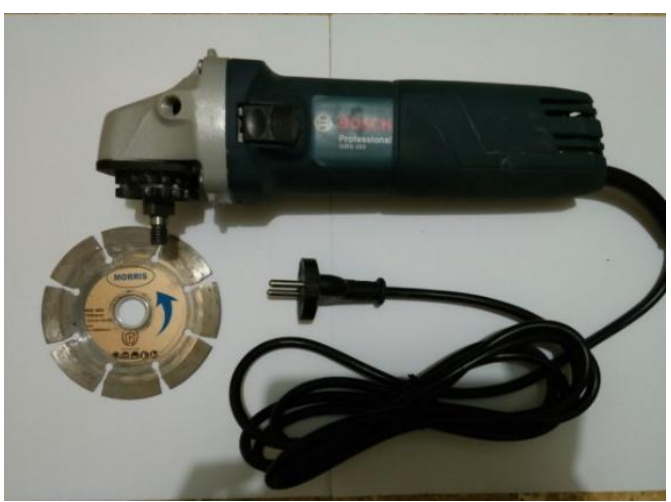

Gambar 3. Mesin Gerinda

\section{d) Genset}

Genset digunakan sebagai sumber listrik dari peralatan yang digunakan. Perlu digunakan genset dengan kapasitas besar sehingga dapat digunakan untuk mendukung penggunaaan alat secara bersamaan. Pada penelitian ini digunakan genset dengan merk Krisbow Generator Gasoline 2800watt 1ph Open yang dapat menghasilkan daya sebesar 2800 watt.

e) Peralatan core drill

Digunakan untuk mengambil benda uji dilapangan. satu set mesin core drill mencakup mesin core drill, genset, selang air, dan mata bor diameter 10 $\mathrm{cm}$. 


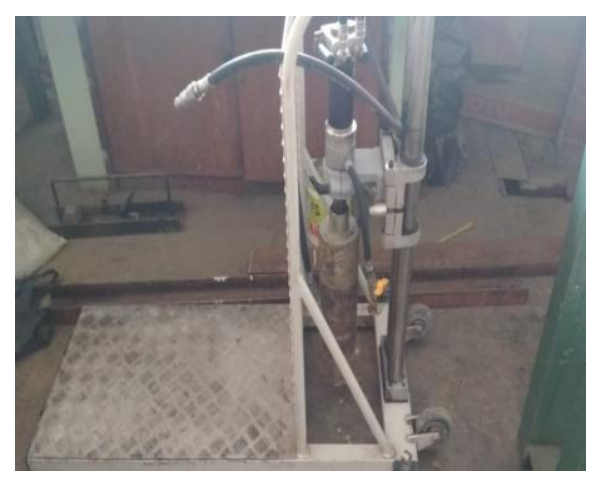

Gambar 4. Mesin Core Drill

f) Peralatan keselamatan kerja

Peralatan keamana sangat diperlukan dalam pelaksanaan pekerjaan dilapangan untuk mengurangi resiko terjadinya kecelakaan kerja, beberapa alat yang digunakan dalam pekerjaan ini adalah safety cone yang digunakan untuk mengatur lalulintas, lampu penerangan sebagai sumber penerangan dimalam hari, light stick digunakan sebagai penanda bahwa di tempat tersebut sedang dilakukan kegiatan perbaikan, serta APD yang berfungsi untuk melindungi tubuh dari potensi bahaya di tempat kerja.

2) Bahan yang digunakan

a) Epoxy Grout

Epoxy resins adalah material dengan campuran antara resin dengan hardener (pengeras). Material ini memiliki kekuatan yang sangat besar dan waktu setting yang cepat, tetapi harganya mahal. Contoh dari material ini adalah Conbextra EP10 TG. Material ini memiliki kekuatan kompresif hingga $83 \mathrm{~N} / \mathrm{mm} 2$, kekuatan lentur hingga $63 \quad 83 \mathrm{~N} / \mathrm{mm} 2$, daya Tarik hingga $26 \mathrm{~N} / \mathrm{mm} 2$ dan masa jenis sebesar $1050 \mathrm{~kg} / \mathrm{m}$.

\section{b) Polyurethane Grout}

Polyurethane adalah material yang dapat digunakan untuk menutup keretakan pada struktur beton. Material ini bereaksi dengan air, mengembang, dan membentuk foam yang bisa menutup keretakan. Pada penelitian ini digunakan material polyurethane dengan merk JTCC seri CYH-500. Material ini dapat digunakan untuk menambal crack pada struktur beton material foam dapat mengembang hingga 3 kali ukuran awal.

c) Patching Material

Berfungsi sebagai seal yang digunakan untuk menutup keretakan pada beton agar material grouting tidak keluar dari keretakan pada saat dilakukan injeksi. Contoh material ini adalah Nitobond EC.

b. Pelaksanaan grouting

1. Perapihan keretakan

Pekerjaan ini merupakan pekerjaan pertama dalam rangkaian pekerjaan injeksi beton. Dilakukan dengan tujuan untuk merapikan keretakan sehingga mudah pada saat dilakukan injeksi. Pekerjaan ini mencakup perapihan dan pemasangan nipple.

2. Pekerjaan patching

Pekerjaan ini bertujuan untuk menutup lubang keretakan agar material injeksi tidak keluar dari lubang keretakan pada saat dilakukan penyuntikan.

3. Pelaksanaan Penyuntikan

Untuk perbaikan menggunakan material polyurethane, tidak ada campuran yang digunakan sehingga langsung dapat digunakan dan dimasukkan kedalam tabung pompa mesin injeksi. Sedangkan untuk penggunaan material epoxy, digunakan 
campuran material dengan perbandingan 3 (base): 1 (hardener). Material yang sudah disiapkan, selanjutnya dipompa melalui sebuah selang yang dihubungkan pada alat penyuntik yang kemudian disuntikkan ke dalam retakan beton melalui nipple. Penyuntikan dilakukan pada salah satu nipple yang terbuka, hentikan penyuntikan apabila material pengisi sudah keluar melalui nipple yang terbuka pada ujung yang berbeda, kemudian tutup semua nipple dan tunggu sampai material mengeras kurang lebih selama 3 jam. Selanjutnya dilakukan pemotongan nipple dan penambalan menggunakan material patching.

\section{c. Pengambilan benda uji}

Pengambilan benda uji dilakukan 7 hari setelah pelaksanaan injeksi, menggunakan metode core drill dengan diameter benda uji $10 \mathrm{~cm}$ dan panjang $20 \mathrm{~cm}$ sebanyak 15 sampel terdiri dari 5 sampel beton eksisting normal (tidak rusak), 5 sampel beton yang diperbaiki menggunakan material epoxy dan 5 beton yang diperbaiki menggunakan material polyurethae.

\section{d. Pengujian benda uji}

Setelah pelaksanaan pekerjaan core drill di lapangan, dilakukan pengujian benda uji berupa pengujian kuat tekan di laboratorium. Terdapat 15 sampel yang akan diuji yang terdiri dari 5 sampel beton eksisting normal (tidak rusak), 5 sampel beton yang diperbaiki menggunakan material epoxy dan 5 beton yang diperbaiki menggunakan material polyurethae. 


\section{HASIL DAN PEMBAHASAN}

Pengujian kuat tekan pada penelitian ini menggunakan 2 jenis metode, yaitu dengan metode hammer test dan menggunakan mesin uji tekan (compression machine). Pada pengujian kuat tekan menggunakan metode hammer test dilakukan pada beton eksisting yang mengalami keretakan yaitu sebanyak 12 bidang uji keretakan dengan setiap keretakan dilakukan 5 titik dengan arah pukulan $90^{\circ}$. Sedangkan uji kuat tekan dengan mesin uji tekan (compression machine) menggunakan benda uji berbentuk silinder yang berukuran $10 \times 20 \mathrm{~cm}$ sebanyak 5 buah dengan 3 jenis benda uji yang berbeda, yaitu beton eksisting normal, beton yang diperbaiki dengan menggunakan material epoxy dan beton yang diperbaiki dengan menggunakan material polyurethane.

a. Beton eksisting normal (tidak rusak)

Hasil dari pelaksanaan core drill pada beton eksisting normal (tidak rusak), kemudian dilakukan pengujian dan diperoleh 5 sampel yang dianalisa berdasarkan SNI 1974-2011 tentang cara uji kuat tekan beton dengan benda uji silinder. Adapun hasil yang didapatkan adalah seperti pada tabel 1 di bawah.

b. Beton eksisting rusak (retak)

Pengujian hammer dilakukan sepanjang garis keretakan untuk memperoleh nilai kekuatan beton eksisting retak. Pada pengujian ini diambil lima pukulan pada setiap titik untuk mendapatkan nilai rebound yang akan dianalisa berdasakan SNI 03-4430-1997 tentang Metode pengujian elemen struktur beton dengan alat palu beton tipe $\mathrm{N}$ dan NR. Adapun hasil yang didapatkan adalah seperti pada tabel 2 di bawah.

c. Perbaikan beton dengan epoxy Hasil dari pelaksanaan core drill pada beton retak yang telah diperbaiki dengan menggunakan material epoxy, kemudian dilakukan pengujian dan diperoleh 5 sampel yang dianalisa berdasarkan SNI 1974-2011 tentang cara uji kuat tekan beton dengan benda uji silinder. Adapun hasil yang didapatkan adalah seperti pada tabel 3 di bawah.

Tabel 1. Data hasil pengujian kuat tekan beton eksisting normal

\begin{tabular}{|l|c|c|c|c|}
\hline No & Kode & $\begin{array}{c}\text { Kuat } \\
\text { tekan } \\
(\mathrm{N} / \mathrm{mm} 2)\end{array}$ & $\begin{array}{c}\text { Rata- } \\
\text { rata }\end{array}$ & Ket. \\
\hline 1 & $P 16$ & 48.56 & & \\
\hline 2 & $P 17$ & 63.29 & & \\
\hline 3 & $P 18$ & 59.20 & 59.20 & Eksisting \\
\hline 4 & $P 19$ & 61.72 & & \\
\hline 5 & $P 20$ & 63.24 & & \\
\hline
\end{tabular}


Tabel 2. Data hasil analisa hammer test pada beton eksisting rusak

\begin{tabular}{|l|c|c|c|c|}
\hline No & Kode & $\begin{array}{c}\text { Kuat } \\
\text { tekan } \\
\text { N/mm2 })\end{array}$ & $\begin{array}{c}\text { Rata- } \\
\text { rata }\end{array}$ & Ket. \\
\hline 1 & $P 1$ & 26,20 & & \\
\hline 2 & $P 2$ & 27,80 & & \\
\hline 3 & $P 3$ & 27,80 & 27,04 & Retak \\
\hline 4 & $P 4$ & $\begin{array}{l}26,00 \\
26\end{array}$ & \\
\hline 5 & $P 5$ & 27,40 & & \\
\hline
\end{tabular}

Tabel 3. Data hasil pengujian kuat tekan beton epoxy

\begin{tabular}{|l|c|c|c|c}
\hline No & Kode & $\begin{array}{c}\text { Kuat } \\
\text { tekan } \\
(\mathrm{N} / \mathrm{mm} 2)\end{array}$ & $\begin{array}{c}\text { Rata- } \\
\text { rata }\end{array}$ & Ket. \\
\hline 1 & $P 8$ & 38.72 & & \\
\hline 2 & $P 11$ & 29.64 & & \\
\hline 3 & $P 12$ & 49.23 & 45.22 & Epoxy \\
\hline 4 & $P 13$ & 63.54 & & \\
\hline 5 & $P 15$ & 44.98 & & \\
\hline
\end{tabular}

d. Perbaikan beton dengan polyurethane

Hasil dari pelaksanaan core drill pada beton retak yang telah diperbaiki dengan menggunakan material polyurethane, kemudian dilakukan pengujian dan diperoleh 5 sampel yang dianalisa berdasarkan SNI 1974-2011 tentang cara uji kuat tekan beton dengan benda uji silinder. Adapun hasil yang didapatkan adalah seperti pada tabel 4 di bawah.

Berdasarkan data hasil pengujian diperoleh nilai kekuatan beton dari 4 variasi yang berbeda yang dijelaskan pada Gambar 6.
Berdasarkan Gambar 6 diatas, dapat disimpulkan bahwa nilai kekuatan tekan dari 4 variasi yang digunakan dalam penelitian ini memiliki berbagai variasi nilai kuat tekan yang berbeda-beda. Sehingga dari data tersebut tidak dapat langsung disimpulkan hasil dari pengujian kuat tekan tersebut, maka dari itu perlu dilakukan analisa statistika dengan menggunakan SPSS 2016 yaitu menggunakan pengujian varian Anova dengan metode Tukey HSD dan didapatkan data seperti pada tabel 5 di bawah. 
Tabel 4. Data hasil pengujian kuat tekan beton polyurethane

\begin{tabular}{|c|c|c|c|c|}
\hline No & Kode & $\begin{array}{c}\text { Kuat } \\
\text { tekan } \\
(\mathrm{N} / \mathrm{mm} 2)\end{array}$ & $\begin{array}{l}\text { Rata- } \\
\text { rata }\end{array}$ & Ket. \\
\hline 1 & $P 1$ & 36.63 & & \\
\hline 2 & $P 5$ & 22.66 & & \\
\hline 3 & $P 7$ & 25.31 & 31.92 & Polymer \\
\hline 4 & $P 9$ & 30.20 & & \\
\hline 5 & $P 10$ & 44.82 & & \\
\hline
\end{tabular}

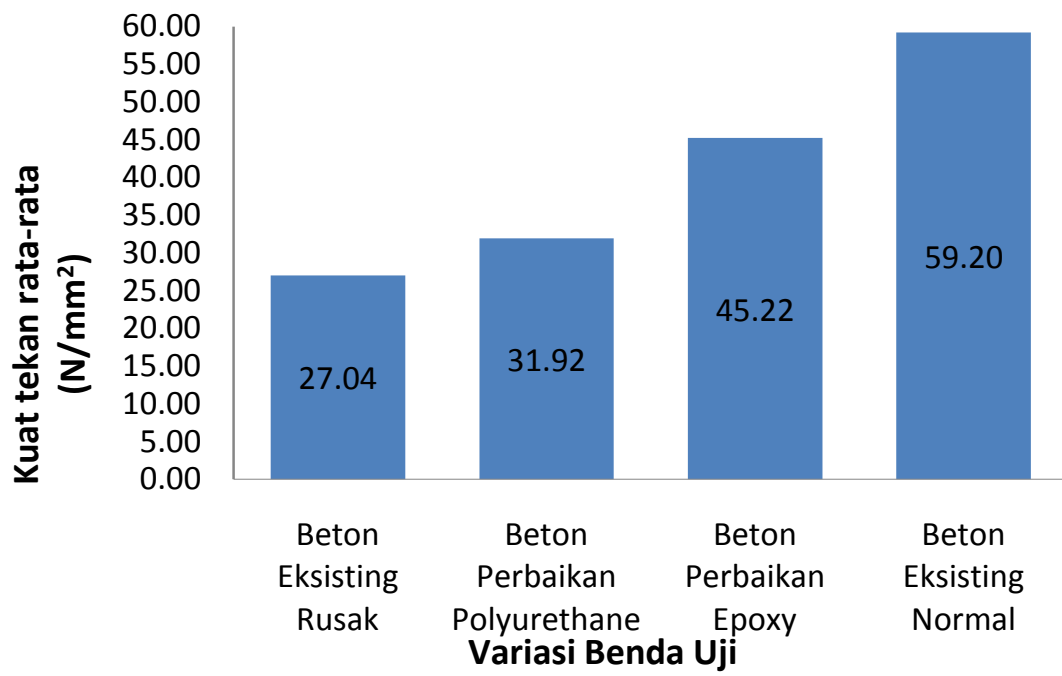

Gambar 6. Perbandingan kekuatan benda uji.

Tabel 5. Hasil analisa data metode Tukey HSD

\begin{tabular}{|c|c|c|c|c|c|c|}
\hline \multirow{2}{*}{$\begin{array}{l}\text { (I) Jenis } \\
\text { Percobaan }\end{array}$} & \multirow{2}{*}{$\begin{array}{l}\text { (J) Jenis } \\
\text { Percobaan }\end{array}$} & \multirow{2}{*}{$\begin{array}{c}\text { Mean Difference } \\
(\mathrm{I}-\mathrm{J})\end{array}$} & \multirow[b]{2}{*}{ Std. Error } & \multirow[b]{2}{*}{ Sig. } & \multicolumn{2}{|c|}{ 95\% Confidence Interval } \\
\hline & & & & & \begin{tabular}{l|} 
Lower \\
Bound
\end{tabular} & $\begin{array}{l}\text { Upper } \\
\text { Bound }\end{array}$ \\
\hline \multirow{3}{*}{$\begin{array}{l}\text { Eksisting } \\
\text { Rusak }\end{array}$} & Polyurethane & -4.88400 & 5.27594 & 0.792 & -19.9786 & 10.2106 \\
\hline & Epoxy & -18.18200 & 5.27594 & 0.016 & -33.2766 & -3.0874 \\
\hline & Eksisting Normal & -32.16200 & 5.27594 & 0.000 & -47.2566 & -17.0674 \\
\hline \multirow{3}{*}{ Polyurethane } & Eksisting Rusak & 4.88400 & 5.27594 & 0.792 & -10.2106 & 19.9786 \\
\hline & Epoxy & -13.29800 & 5.27594 & 0.094 & -28.3926 & 1.7966 \\
\hline & Eksisting Normal & -27.27800 & 5.27594 & 0.000 & -42.3726 & -12.1834 \\
\hline \multirow{3}{*}{ Epoxy } & Eksisting Rusak & 18.182 & 5.27594 & 0.016 & 3.0874 & 33.2766 \\
\hline & \begin{tabular}{|l|} 
Polyurethane \\
\end{tabular} & 13.29800 & 5.27594 & 0.094 & -1.7966 & 28.3926 \\
\hline & Eksisting Normal & -13.98000 & 5.27594 & 0.075 & -29.0746 & 1.1146 \\
\hline \multirow{3}{*}{$\begin{array}{r}\text { Eksisting } \\
\text { Normal }\end{array}$} & Eksisting Rusak & 32.162 & 5.27594 & 0.000 & 17.0674 & 47.2566 \\
\hline & \begin{tabular}{|l|} 
Polyurethane \\
\end{tabular} & $27.27800^{\prime}$ & 5.27594 & 0.000 & 12.1834 & 42.3726 \\
\hline & Epoxy & 13.98000 & 5.27594 & 0.075 & -1.0937 & 29.0746 \\
\hline
\end{tabular}

Berdasarkan pembacaan tabel diatas diketahui bahwa: a. Ditinjau dari nilai beton eksisting rusak (retak) 
Jika dibandingkan dengan nilai beton yang diperbaiki dengan polyurethane diasumsikan memiliki nilai kuat tekan yang sama karena memiliki nilai $\alpha=$ 0.792 (lebih dari 0.05). Jika dibandingkan dengan nilai beton yang diperbaiki dengan epoxy diasumsikan memiliki nilai kuat tekan yang berbeda karena memiliki nilai $\alpha=0.016$ (kurang dari 0.05). Jika dibandingkan dengan nilai beton eksisting normal diasumsikan memiliki nilai kuat tekan yang berbeda karena memiliki nilai $\alpha=$ 0.000 (kurang dari 0.05).

b. Ditinjau dari beton yang diperbaiki dengan polyurethane

Jika dibandingkan dengan nilai beton eksisting rusak (retak) diasumsikan memiliki nilai kuat tekan yang sama karena memiliki nilai $\alpha=0.792$ (lebih dari 0.05). Jika dibandingkan dengan nilai beton yang diperbaiki dengan epoxy diasumsikan memiliki nilai kuat tekan yang sama karena memiliki nilai $\alpha=0.094$ (lebih dari 0.05). Jika dibandingkan dengan nilai beton eksisting normal diasumsikan memiliki nilai kuat tekan yang berbeda karena memiliki nilai $\alpha=0.000$ (kurang dari 0.05).

c. Ditinjau dari beton yang diperbaiki dengan epoxy
Jika dibandingkan dengan nilai beton eksisting rusak (retak) diasumsikan memiliki nilai kuat tekan yang berbeda karena memiliki nilai $\alpha=0.016$ (kurang dari 0.05). Jika dibandingkan dengan nilai beton yang diperbaiki dengan polyurethane diasumsikan memiliki nilai kuat tekan yang sama karena memiliki nilai $\alpha=0.094$ (lebih dari 0.05). Jika dibandingkan dengan nilai beton eksisting normal diasumsikan memiliki nilai kuat tekan yang sama karena memiliki nilai $\alpha=$ 0.075 (lebih dari 0.05).

d. Ditinjau dari beton eksisting normal (tidak rusak)

Jika dibandingkan dengan nilai beton eksisting rusak (retak) diasumsikan memiliki nilai kuat tekan yang berbeda karena memiliki nilai $\alpha=0.000$ (kurang dari 0.05). Jika dibandingkan dengan nilai beton yang diperbaiki dengan polyurethane diasumsikan memiliki nilai kuat tekan yang berbeda karena memiliki nilai $\alpha=0.000$ (kurang dari 0.05). Jika dibandingkan dengan nilai beton yang diperbaiki dengan epoxy diasumsikan memiliki nilai kuat tekan yang sama karena memiliki nilai $\alpha=0.075$ (lebih dari 0.05).

Tabel 6. Homogeneous subset metode Tukey HSD

\begin{tabular}{|l|c|c|c|c|}
\hline & \multirow{2}{*}{ Jenis Percobaan } & \multicolumn{3}{|c|}{ Subset for alpha $=0.05$} \\
\cline { 3 - 5 } & & 1 & 2 & 3 \\
\hline Eksisting Rusak & 5 & 27.040 & & \\
\hline Polyurethane & 5 & 31.924 & 31.924 & \\
\hline Epoxy & 5 & & 45.222 & 45.222 \\
\hline Eksisting Normal & 5 & & & 59.202 \\
\hline Sig. & & 0.792 & 0.094 & 0.075 \\
\hline
\end{tabular}


Berdasarkan analisa Anova metode Tukey dengan menggunakan nilai kuat tekan rata-rata 4 variasi dapat disimpulkan sebagai berikut:

a. Perbaikan beton retak menggunakan material polyurethane dianggap sama atau tidak berpengaruh terhadap kekuatan beton rusak (1).

b. Penggunaan material polyurethane dan epoxy dianggap memiliki pengaruh terhadap perbaikan keretakan beton (2).

c. Penggunaan material epoxy dianggap berpengaruh terhadap perbaikan keretakan beton karena memiliki nilai yang dianggap sama dengan beton eksisting (3).

\section{SIMPULAN}

Berdasarkan hasil analisis dan pembahasan yang diuraikan diatas, dapat disimpulkan bahwa nilai kekuatan tekan rata-rata pada beton eksisting normal (tidak rusak) sebesar $59,20 \mathrm{~N} / \mathrm{mm} 2$. Setelah mengalami keretakan, nilai kekuatan tekan ratarata pada beton mengalami penurunan menjadi sebesar 27,04 N/mm2. Perbaikan pada keretakan beton dengan menggunakan material polyurethane menghasilkan nilai kekuatan tekan rata-rata sebesar 31,92 $\mathrm{N} / \mathrm{mm} 2$ sedangkan perbaikan keretakan pada beton menggunakan material epoxy menghasilkan nilai kekuatan tekan rata-rata sebesar 45,22 $\mathrm{N} / \mathrm{mm} 2$. Kekuatan tekan beton eksisting rusak sebesar 27,04 N/mm2 meningkat setelah dilakukan perbaikan menggunakan material polyurethane menjadi $31.92 \mathrm{~N} / \mathrm{mm} 2$ dengan nilai efektifitas sebesar 15,17\% sedangkan kekuatan tekan beton eksisting rusak sebesar 27,04 N/mm2 meningkat setelah dilakukan perbaikan menggunakan material epoxy menjadi 45,22 N/mm2 dengan nilai efektifitas sebesar 56,53 \%. Hasil penelitian menunjukkan bahwa penggunaan material epoxy dalam perbaikan struktur beton menggunakan metode pressure grouting lebih baik daripada material polyurethane.

\section{DAFTAR PUSTAKA}

Aggarwal, L.K., Thapliyal, P.C., Karade, S.R., 2007, Properties of Polymer Modified Mortars Using Epoxy and Acrylic Emulsion. Construction and Building Material. Vol.21, Hal.379-383.

Alfredo, D., Hutomo, K., Sudjarwo, P., Buntro. J., 2014, Analisa Penyebab dan Metode Perbaikan yang Tepat pada Beton yang Disebabkan oleh Faktor Non-Struktural. Tesis Program Studi Teknik Sipil Universitas Kristen Petra Surabaya. Jurnal Dimensi Pratama Teknik Sipil. Vol.3, No.2, Hal.1-5.

Dachlan, A.T, 2010, Metode Pelaksanaan Evaluasi Perbaikan Jalan Beton Dengan Injeksi Semen, Cor di Tempat Dan Beton Pra Cetak. Jurnal Jalan - Jembatan. Vol.27, No.2, Hal.125-142.

Isneini, M., 2009, Analisis Modulus Elastisitas Lentur Terhadap Loss Factor Beton Polimer. 
Jurnal Rekayasa. Vol.13, No.1, Hal.67-76.

Kementerian Pekerjaan Umum dan

Perumahan Rakyat, 2015, Pedoman Penstabilan Dan Pengembalian Elevasi Pelat Beton Dengan Cara Grouting Pada Perkerasan Kaku. Surat Edaran Menteri PUPR No. 27. Jakarta

Kusdiyono, 2012, Bahan Bangunan 2, Penerbit Polines Semarang. Semarang.

Primasasti, D.K., 2010, Tinjauan Kuat Tekan dan Kuat Lentur Repair Mortar Dengan Bahan Tambah Polymer. Skripsi Jurusan teknik
Sipil Fakultas Teknik Universitas Sebelas Maret. Surakarta.

Supardi., 2013, Evaluasi Kerusakan Jalan Pada Perkerasan Rigid dengan Menggunakan Metode Bina Marga (Studi Kasus Ruas Jalan Sei Durian Rasau Jaya km $21+700$ s.d $k m 24+700)$. Jurnal Garuda. Vol 13, No. 1, Hal. 129-138.

Yurmansyah, I., Mukhlisin, 2009, Perkuatan Struktur Beton Gedung dengan Metode Grouting dan Glass Fiber. Jurnal Rekayasa Sipil. Vol.V, No.1, Hal.46-59. 